\title{
Introduction to the Research Handbook on Human Rights and Poverty
}

Poverty is both pervasive and predictable across the globe. It exacerbates the impact of catastrophes from hurricanes to pandemics and heightens human-caused challenges such as economic downturns and discrimination. Poor people are likely to experience more hardship and distress than others on a daily basis. These everyday stresses are dramatically increased, and made more visible, when nations, regions, neighborhoods, families or individuals face unanticipated calamities or confront structural inequalities.

Yet despite its ubiquity, myths about the nature of poverty persist. These include the notion that poverty is a matter of individual choice or a product of culture, and the idea that poverty is an inevitable and tolerable outcome of generalized economic progress.

Examining poverty through a human rights lens directly challenges these myths and contributes new insights. A human rights perspective on poverty raises important questions regarding the role of governmental entities - particularly nation States and international institutions - in perpetuating poverty by failing to meet their obligations to prevent and alleviate it and to respect, protect and fulfil human rights. At the same time, the human rights perspective, which brings together civil, political, economic, social and cultural rights, illuminates the myriad ways in which this failure affects the opportunities of both individuals and groups to live with dignity, autonomy and meaning. Human rights-based approaches also have the potential to identify new sites and strategies for interventions that address root causes, empower rights-holders and hold duty bearers accountable.

The premise of this volume is that there is more research to be done to explore these aspects of the human rights lens, while also challenging some of the assumptions underlying modern human rights concepts. Why, for example, should human rights obligations be limited to public actors and not encompass all key power holders? And why should explorations of poverty stop short of examining political inequality, or overlook the spatial aspects of deprivation? The chapters that make up this volume outline the status quo of poverty and human rights and raise probing questions about that status quo. They also respond to important critiques of the human rights project and point toward future research to further hone our understandings of the issues, a necessary step toward crafting more effective responses.

In this introductory essay, we first identify common groundings that serve as through-lines for the chapters in this volume. We then introduce the themes of the book as expressed in the chapters themselves.

\section{POVERTY BASICS}

\section{A. What Is Poverty?}

It is no surprise that a phenomenon as complex and varied as poverty has no single accepted definition. Below, we review several approaches as background for the chapters that follow. 
Some of these chapters explore definitional questions in greater detail; others assume a common understanding of poverty or rely on everyday, specific examples as a basis for contextualizing the discussion without seeking to define the term. Regardless, a brief survey of the range of definitions is a useful starting point before reading further.

Many governments and institutions focus on income as a sole or primary poverty measure, though this approach is increasingly subject to criticism. Some national poverty lines - including the European Union's (EU) standards - define the poverty threshold as households with disposable income below the 60 percent median income level. ${ }^{1}$ Similarly, the United States (US) has an established poverty line based on bright line indicators of household income and assets relative to expected consumption levels. ${ }^{2}$ The World Bank pegs extreme poverty at $\$ 1.90 /$ day, though it also recognizes that inequality is an important component of assessing poverty levels. ${ }^{3}$ The understanding of poverty as a multidimensional phenomenon is central to the design of the Sustainable Development Goals (SDGs), yet they also define extreme poverty in economic terms, as people living on less than $\$ 1.90$ a day. ${ }^{4}$

More nuanced poverty definitions eschew strict financial calculations and define poverty in relation to social deprivation, including inequality. For example, the 2001 statement of the Committee on Economic, Social and Cultural Rights (CESCR) defines poverty as 'a human condition characterized by the sustained or chronic deprivation of the resources, capabilities, choices, security and power necessary for the enjoyment of an adequate standard of living and other civil, cultural, economic, political and social rights'. ${ }^{5}$ This definition reflects the influence of scholars such as Amartya Sen and Martha Nussbaum who identify 'capabilities' as a key component of the experience of poverty. ${ }^{6}$

Comparing poverty across geographies and borders is particularly complex but necessary in a globalized world. The Oxford Poverty and Human Development Initiative (OPHI) has developed a Multidimensional Poverty Index (MPI) to measure non-monetary comparative poverty over time. ${ }^{7}$ Using three dimensions (health, education and standard of living) and ten indicators (for example, the indicators for health are nutrition and child mortality), the MPI

\footnotetext{
1 Zsolt Darvas, 'Why is it so Hard to Reach the EU's "Poverty" Target?' (Bruegel, 2017) $2<$ http:// aei.pitt.edu/83767/1/PC-01-2017-1.pdf> accessed 22 July 2020.

2 United States Census Bureau, 'How the Census Bureau Measures Poverty' (27 August 2019) $<$ www.census.gov/topics/income-poverty/poverty/guidance/poverty-measures.html > accessed 22 July 2020.

Roy Katayama and Divyanshi Wadhwa, 'Half of the World's Poor Live in Just 5 Countries' (World Bank Blogs, 2019) <https://blogs.worldbank.org/opendata/half-world-s-poor-live-just-5-countries> accessed 22 July 2020.

4 United Nations (UN), 'Goal 1: End Poverty in all its Forms Everywhere' <www.un.org/sus tainabledevelopment/poverty/> accessed 22 July 2020.

5 United Nations Committee on Economic, Social and Cultural Rights (CESCR), 'Substantive Issues Arising in the Implementation of the International Covenant on Economic, Social and Cultural Rights: Poverty and the International Covenant on Economic, Social and Cultural Rights' (10 May 2001) UN Doc E/C.12/2001/10, para. 8 .

6 Amartya Sen, 'Human Rights and Capabilities' (2005) 6(2) Journal of Human Development 151, 155; Martha Nussbaum, 'Poverty and Human Functionings: Capabilities as Fundamental Entitlements' in David B. Grusky and Ravi Kanbur (eds), Poverty and Inequality (Stanford University Press 2007) $47-75,53$.

7 Oxford Poverty \& Human Development Initiative, 'Global Multidimensional Poverty Index' $<$ https://ophi.org.uk/multidimensional-poverty-index/> accessed 24 July 2020.
} 
is designed to illuminate who is poor, why they are poor, and the intensity of their poverty. ${ }^{8}$ Note that this approach is intended to complement income-based poverty measures rather than supplant them.

In sum, poverty measures in use today may be objective or subjective, absolute or contextual. While purely economic measures can facilitate governmental analyses and comparisons, these measures are incomplete. Poverty is most fully described and defined when human experiences, including human rights impacts, are taken into account.

\section{B. Human Rights Institutions and Poverty}

Many of the chapters in this volume either build on, or challenge, the work done by human rights institutions to articulate the connections between human rights and poverty. In this section, we briefly describe the backdrop of that institutional work.

As early as 1944, the International Labour Organization affirmed that 'poverty anywhere constitutes a danger to prosperity everywhere', and explicitly linked the 'war against want' to social justice goals. ${ }^{9}$ Four years later, the Universal Declaration of Human Rights (UDHR) articulated the 'freedom from fear and want' in its preamble and affirmed the fundamental right to an adequate standard of living. ${ }^{10}$

Building on the UDHR, the International Covenant on Economic, Social and Cultural Rights (ICESCR) reinforced in Article 11 'the right of everyone to an adequate standard of living for himself and his family, including adequate food, clothing and housing, and to the continuous improvement of living conditions' as well as the 'fundamental right of everyone to be free from hunger'. ${ }^{11}$ The CESCR has made clear its position that poverty, by its own definition, constitutes a denial of human rights. For example, in its General Comment 19 discussing Article 9 of the ICESCR, the Committee stated that '[s]ocial security, through its redistributive character, plays an important role in poverty reduction and alleviation', thereby enabling individuals to enjoy their rights under the Covenant. ${ }^{12}$

The UN's work rests on the three pillars of development, peace and human rights; the struggle to end poverty has gradually made these three dimensions more interrelated and interconnected. The 1992 Rio Declaration on Environment and Development recognized that eradicating poverty is an indispensable requirement for sustainable development. ${ }^{13}$ In 1995 , Chapter 2 of the Programme of Action of the Copenhagen Summit on Social Development

8 Oxford Poverty \& Human Development Initiative \& UN Development Program, Charting Pathways Out of Multidimensional Poverty: Achieving the SDGs (2020) 4-5 <https://ophi.org.uk/wp -content/uploads/G-MPI_Report_2020_Charting_Pathways.pdf> accessed 29 July 2020.

9 International Labour Organization (ILO) Constitution, 'Annex: Declaration of Philadelphia' (10 May 1944) <www.ilo.org/legacy/english/inwork/cb-policy-guide/declarationofPhiladelphia1944.pdf> accessed 24 July 2020.

10 Universal Declaration of Human Rights (adopted 10 December 1948 UNGA Res 217 A(III) (UDHR) art 25.

${ }_{11}$ International Covenant on Economic, Social and Cultural Rights (adopted 16 December 1966, adopted into force 3 January 1976) UNGA Res 2200A (XXI) (ICESCR) art 11.

12 CESCR, 'General Comment No. 19: The Right to Social Security (Art. 9 of the Covenant)' (4 February 2008) UN Doc E/C.12/GC/19.

13 Rio Declaration On Environment and Development (12 August 1992) UNGA A/Conf.151/26 vol 1. 
was devoted to poverty eradication. ${ }^{14}$ The UN's Millennium Development Goals, in effect from 2000-15, identified eradication of extreme poverty and hunger as the first of eight goals.

Building on these precedents, the SDGs - in effect from 2015 to 2030 - include the target of eradicating extreme poverty for all people everywhere and reducing at least by half the proportion of men, women and children of all ages living in poverty in all its dimensions according to national definitions. ${ }^{15}$ The SDGs acknowledge that the 'tyranny of poverty' is a multidimensional phenomenon occurring in developed and developing countries, and its eradication is the 'greatest global challenge and an indispensable requirement for sustainable development' ${ }^{16}$ Notably, the SDGs incorporate human rights norms more fully than any of the UN's previous development initiatives, a fact that has been reiterated on numerous occasions since their adoption. ${ }^{17}$

The successive UN Special Rapporteurs on Extreme Poverty and Human Rights have spoken directly to the issue of poverty as a human rights violation. For example, former Special Rapporteur Magdalena Sepúlveda Carmona developed the Guiding Principles on Poverty and Human Rights. These Principles, endorsed by the UN Human Rights Council in 2012, explicitly identify poverty as 'an urgent human rights concern', that is 'both a cause and a consequence of human rights violations' ${ }^{18}$

Despite global attention, extreme poverty worldwide has decreased at a glacial pace in recent years. ${ }^{19}$ Moreover, progress at the global and even national levels often hides intractable, entrenched poverty among vulnerable groups.

Philip Alston, the Special Rapporteur on Extreme Poverty from 2014 to 2020 and author of the Foreword to this volume, has pointedly observed that poverty is a 'political choice'. ${ }^{20}$ This choice will be tested when the international community and states devise their policies for building back following the COVID-19 crisis, which has the dangerous potential to increase extreme poverty and thereby reverse the slow but positive trends of recent decades.

\section{OVERVIEW OF THE BOOK}

The chapters in this volume break new ground both by critically examining historic approaches to poverty and human rights and proposing new perspectives to move beyond the impasses that mark the current moment. The diverse group of contributing authors hail from six continents

\footnotetext{
14 Copenhagen Declaration on Social Development (14 March 1995) UNGA A/Conf.166/9.

15 SDG 1.

16 UN, 'Transforming our World: the 2030 Agenda for Sustainable Development' <https://su stainabledevelopment.un.org/post2015/transformingourworld > accessed 26 July 2020.

17 UN, 'Human Rights and the 2030 Agenda for Sustainable Development' <www.ohchr.org/EN/ Issues/SDGS/Pages/The2030Agenda.aspx> accessed 26 July 2020.

18 United Nations Human Rights Office of the High Commissioner (OHCHR), 'Guiding Principles on Extreme Poverty and Human Rights' (27 September 2012)<www.ohchr.org/Documents/Publications/ OHCHR_ExtremePovertyandHumanRights_EN.pdf $>$ accessed 27 July 2020.

19 World Bank, 'Decline of Global Extreme Poverty Continues but has Slowed: World Bank' (19 September 2018) <www.worldbank.org/en/news/press-release/2018/09/19/decline-of-global-extreme -poverty-continues-but-has-slowed-world-bank> accessed 27 July 2020.

20 See for examples OHCHR, 'Statement on Visit to the United Kingdom, by Philip Alston, United Nations Special Rapporteur on Extreme Poverty and Human Rights' (16 November 2018) <www.ohchr .org/en/NewsEvents/Pages/DisplayNews.aspx?NewsID=23881\&LangID=E $>$ accessed 27 July 2020.
} 
and draw their expertise from their roles as current or former UN special procedure mandate holders, treaty body experts, scholars, advocates and activists.

There are many cross-cutting themes in these 35 chapters and many ways that these rich writings might have been meaningfully grouped. In the end, we chose to divide the chapters between four broad Parts: I. Definitions, Measurements and Standards; II. Cross-currents Identity, Place and Participation; III. Mechanisms and Policies; and IV. Structural Barriers. Here, we provide an overview of the Parts and chapters that we hope will introduce the range of topics while also inviting readers to make new connections between the Parts and chapters that will be of value to continued research in this field.

\section{PART I: DEFINITIONS, MEASUREMENTS AND STANDARDS}

This Part takes as a starting place the belief that shared definitions of poverty and common understandings of how to measure it are essential to crafting, implementing and assessing responses to poverty.

In the opening chapter in this Part, Olivier De Schutter, the current UN Special Rapporteur on Extreme Poverty, proposes an understanding of poverty that goes beyond income-based measures and even multidimensional approaches focused on entitlements. He proposes a more intentional focus on the processes of social exclusion that create and perpetuate poverty. Following on De Schutter's contribution, Magdalena Sepúlveda Carmona, who served in the Special Rapporteur role from 2008 to 2014, traces the growing adoption of a more complex understanding of poverty, particularly in the SDGs, and calls for greater attention to stigma and shame as a mechanism by which the social exclusion of the poor is effectuated. Taking a step back to provide a theoretical grounding for this definitional discussion, Ayşe Buğra examines three distinct perspectives in the study of poverty: capabilities, rights and social exclusion. Applying these, she considers differences and similarities in researching and addressing poverty in the Global North and South as well as the responsibilities of national governments, wealthy countries, and international organizations.

The next two chapters, the first by Gillian MacNaughton and the second by Karolina Januszewski and Manfred Nowak, challenge the content of the human rights related to poverty by bringing rights traditionally identified as 'civil and political' into the debate. MacNaughton argues that economic inequality is itself a human rights violation that exists independently of specific poverty measures, but which also fills out an understanding of poverty itself. Drawing on feminist critiques, Nowak and Januszewski assert that discussions of poverty, by focusing on social and economic aspects of the issue and never decoupling 'civil and political', have tragically relegated political rights into 'oblivion'. They argue that the connection between poverty and political rights must be recovered and restored.

Finally, Hans-Otto Sano raises important questions about the practical implications of introducing a human rights perspective into poverty reduction initiatives in sub-Saharan Africa. He concludes that human rights-based efforts have played a positive role locally, but human rights thinking has not influenced poverty-reduction policies and national poverty trends significantly. 


\section{PART II: CROSS-CURRENTS}

Poverty and human rights intersect with disability, age, sex, sexual orientation and gender identity/expression, ethnicity, race and other forms of oppression and bases of discrimination. Likewise, dynamics of power and human rights shift over geographic and spatial landscapes, complicated by the movement of peoples across borders and the variability of legal regimes. In each instance, these intersections raise critical issues regarding the political participation of those most affected. These cross-currents are the subject of Part II, addressed in three sections: A. Poverty, Human Rights and Identity; B. Poverty and Human Rights: Intersection with Geography and Place; and C. Poverty and Participation.

\section{A. Poverty, Human Rights and Identity}

In the opening chapter of this section, Gerard Quinn, current UN Special Rapporteur on the rights of persons with disabilities, interrogates the disability-poverty connection and argues that a positive human rights agenda, informed by the principle of 'inclusive equality', can challenge the exclusions of disabled people in both the private and public spheres. Quinn acknowledges that the viability of this positive vision owes much to the 'key breakthrough' represented by the Convention on the Rights of People with Disabilities. Introducing the topic of older persons, poverty and human rights, Andrew Byrnes postulates that a new convention on the rights of older persons might herald a similar breakthrough. The COVID-19 crisis has raised awareness of the many human rights challenges facing subgroups of older individuals, and this momentum might be reinforced by the international attention that a new convention would bring. At the other end of the age spectrum, a treaty addressing children already exists. However, Wouter Vandenhole identifies several significant research questions raised by children's continued impoverishment, a phenomenon that is not inevitable, he avers, but results from policy decisions that deepen global child poverty. He proposes a novel children's rights-based approach to poverty.

The next grouping of chapters addresses intersections of poverty and human rights with sex, sexual orientation and gender identity, and race. Meghan Campbell leads off this section with a deep analysis of gender stereotypes, parenting and poverty traps. Analyzing several social benefits cases from the United Kingdom, she finds hope that a human rights-based approach to poverty grounded in equality rights might counteract policies that exacerbate women's poverty. Victor Madrigal-Borloz, the UN Independent Expert on Sexual Orientation and Gender Identity (SOGI), draws on his country missions to survey the state of SOGI, poverty and human rights. His observations drive home the day to day impacts of social exclusion, specifically naming ' $[\mathrm{t}]$ he price that is paid by LGBT persons who live openly' in diminished human dignity and economic well-being. The case of Romani people in Europe is laid out in the chapter by Margareta Matache and Simona Barbu, who argue that an array of justice-based approaches should be adopted to address the multidimensional challenges of Roma poverty. Gay McDougall's chapter closing this section addresses disproportionate poverty of African descendants in the American hemisphere as a manifestation of racism. A former member of the UN Committee on the Elimination of All Forms of Racial Discrimination (CERD), McDougall extensively analyzes the Committee's findings over time and distills a set of recommendations for States that are serious about addressing and redressing racism and poverty. 


\section{B. Poverty and Human Rights: Intersecting with Geography and Place}

The first two chapters of this section address the situation of people on the move, crossing borders and encountering legal regimes that take poverty into account in both negative and positive ways. Tally Kritzman-Amir specifically notes this tension, observing that human rights law has much to offer to people in need of asylum and non-refoulement, yet destination countries have not always implemented these human rights norms and may even actively contribute to the impoverishment of people in furtherance of anti-refugee and anti-immigrant agendas. Examining European asylum law, Eleni Karageorgiou observes that the very structure of asylum law may discourage the movement of poor people, with the tacit approval of potential destination countries.

Urban poverty and human rights are central to the next two chapters. Natalia Ángel-Cabo and Luisa Sotomayor critique the urban turn in human rights law, ultimately concluding that there is a role for human rights perspectives to contribute to addressing urban poverty but it is no panacea and is less robust than some proponents have suggested. A more hopeful view of the role of local authorities in addressing poverty and implementing human rights is offered by Moritz Baumgärtel, who lays out a series of examples to support his argument that local governments have become central actors in the realization of human rights norms, with potential to do even more.

Miloon Kothari, the UN Special Rapporteur on the Right to Adequate Housing from 2000 to 2008 and an architect by training, argues that the causes of poverty, and potential responses, can be more fully understood through a combination of a human rights and spatial justice approach that examines the role of location in income disparities and persistent poverty. Land rights are the focus of Alfred Brownell, a scholar activist, who draws on his work in West Africa to offer a detailed examination of how land rights are manipulated to make poverty and displacement a pre-determined outcome among Indigenous Peoples in the region. Responding to such concerns for indigenous rights, Alejandro Fuentes mines the jurisprudence of the Inter-American Court of Human Rights to argue that recognition of Indigenous Peoples' right to collective property over their traditional lands and natural resources is an indispensable and promising strategy for poverty reduction that takes into consideration the affected populations' own cultural distinctiveness.

\section{Poverty, Human Rights and Participation}

Participation of those most affected in the development of policy responses is integral to human rights approaches and is a key concern for designing poverty eradication strategies that guarantee human rights in both processes and outcomes. The final two chapters in this Part address participation issues in depth. Resonating with earlier chapters stressing the connection between poverty and political rights, Domingo Lovera-Parmo argues that social protests are protected forms of participating in political affairs - and may be the only type of participation open to poor people who are otherwise marginalized from influencing decisions. Lisa Hilbink and Valentina Salas likewise look at how people living in poverty are often excluded from formal institutions of justice and accountability and argue that advancing human rights requires 'going beyond institutional reforms and taking an approach anchored in legal empowerment' - an approach that reinforces dignity while at the same time requiring a new conception of how justice is achieved. 


\section{PART III: MECHANISMS AND POLICIES}

In this Part, we turn to discussions of policy approaches to poverty and human rights. Though much of this Part is grounded in specific substantive policies and policy approaches, the Part begins with a more theoretical contribution from Volkan Yilmaz. Taking theory seriously, Yilmaz asks 'How can a human rights perspective push the study of ideas and paradigms in social policy toward a better understanding of their human rights implications?' To explore this question and others, Yilmaz offers a critical and contextual analysis of three dominant global paradigms in contemporary social policy literature: new behaviorism, social investment and new universalism.

The human right to housing is the focus of the contribution by Leilani Farha, UN Special Rapporteur on the Right to Housing from 2012 to 2020, and her colleague Kaitlin Schwan. Drawing on their work with the UN mandate, the authors survey the extensive data on financialization of housing and its aggravating impact on poverty. They argue that a 'seismic shift' is needed 'that reclaims the value of housing as home, not as equity'. Mette Hartlev, in turn, explores poverty and the human right to health. Hartlev exposes the ways in which poverty, human rights and health are mutually influencing and then turns to vexing questions on the horizon posed by algorithms and other interfaces between health care, poverty and technology. One specific aspect of women's healthcare has attracted controversy worldwide: abortion. Risa Kaufman and Diana Kasdan examine the issue from the perspective of both poverty and human rights, spelling out implications of this perspective for global and domestic jurisprudence as well as organizing and mobilization.

Privatization is an issue that cuts across social institutions, from prisons to water providers, with many human rights scholars and advocates expressing skepticism about the marketization of services traditionally provided by government. Antonio Barboza-Vergara and Esteban Hoyos-Ceballos, however, ask 'What is wrong with privatization of education' as an anti-poverty policy from a human rights perspective? Grounded in the realities of public education systems that often fail low-income individuals, the authors propose a concrete research agenda designed to give this issue a more complete airing.

Workers' rights are the subject of the next two contributions. Lee Swepston and Constance Thomas explore the human rights perspective on labor standards, arguing that the legal framework that protects workers from exploitation is a bulwark against poverty. Sophal Chea offers a case study from Cambodia testing the impacts of that nation's minimum wage policy on the human rights of workers.

While it is seldom denominated as such, tax policy is among the most widespread means of effectuating social priorities and addressing poverty. Åsa Gunnarsson's chapter provides a cogent analysis of possible rationales for moving away from taxation solely to support income generation and instead, designing tax policy to promote social justice. Human rights-based tax policies can be an important tool in the effort to end extreme poverty.

\section{PART IV: STRUCTURAL BARRIERS}

Externalities and structural flaws in governance mechanisms can have significant implications for both poverty and human rights. Similarly, a narrow focus on government action, inherent in formal human rights frames, fails to address the role of private actors in poverty creation 
and alleviation. The chapters in this Part examine a selection of meta-issues that can exacerbate poverty and human rights violations while also serving as a barrier to implementation of human rights-informed measures to address poverty.

Sumudu Atapattu leads off this section, chronicling the growing recognition of the linkages between climate change, human rights and poverty. Atapattu notes that climate change will undermine both the enjoyment of rights and the efforts to eradicate poverty, and she suggests that a human rights approach to climate change can improve outcomes on both accounts.

Corruption is another significant impediment to the realization of human rights, with particular impacts on poverty. Khulekani Moyo spells out these often-hidden impacts in detail, evaluates the effectiveness of human rights institutions' responses to corruption and asserts that corruption itself constitutes a human rights violation.

In his contribution, Zafer Kizilkaya sheds light on the ways that conflict heightens poverty and exacerbates human rights violations. This area has been under-researched, in part because of the difficulties of collecting data in conflict zones. Kizilkaya concludes by emphasizing the importance of developing conflict resolution approaches informed by human rights and poverty reduction.

Technological changes have significant implications for poverty and human rights. Potential interfaces include data gathering and service delivery, an issue previously raised by Mette Hartlev in the context of health care. Authors Linnet Taylor and Hellen Mukiri-Smith argue that new technologies in these spaces are not neutral tools and must be utilized with due attention to the power and information asymmetries that they reproduce.

Finally, Lucy Williams reminds readers that poverty is created and sustained by private as well as public actors - a point emphasized in earlier chapters by Farha and Schwan (housing) and Brownell (land grabbing). Williams offers a detailed analysis of several recent cases expanding potential liability of international development banks and multinational corporations for human rights violations, arguing that advocates should be consciously developing theories to support claims against these entities as well as governments.

As these 35 chapters, Preface and Foreword document, decades of committed and innovative scholarship and activism have generated a wealth of insights into the crucial linkages between human rights and poverty. The rights-based lenses presented here allow researchers, policymakers and advocates to enrich their understanding of the lived experiences of poverty, the root causes, and the potential for transformation. Our hope with this diverse collection of expert analyses and recommendations is to inspire and orient future research that is committed to understanding and advancing the conditions for all people to live free and equal in dignity and rights.

Martha F. Davis

Morten Kjaerum

Amanda Lyons

Editors 
Martha F. Davis, Morten Kjaerum, and Amanda Lyons - 9781788977517 Downloaded from PubFactory at $04 / 26 / 2023$ 11:48:16AM 